\title{
The Political Economy of Ebola Virus Disease (EVD) in West African Countries

\section{Abstract}

The Ebola virus disease (EVD) was first reported to have been identified in Africa in 1976 when it occurred in south Sudan and Zaire (now Democratic Republic of Congo). Its first occurrence in West Africa was in a 1994 lone infection of an ethnologist in Côte d'Ivoire but in 2014, there was an outbreak in West Africa stemming from an index case in Guinea. After more than a year, the outbreak is still ongoing. The EVD is one of the filoviral hemorrhagic fevers. This paper examined the political economies in West African nations in relation to the management of their natural resources and the resultant susceptibility to an infectious disease outbreak. A review of the African Development Bank Reports from 2007 to 2012 showed that abundant natural resources did not translate to improved economic opportunities but usually a downturn in economic resources and poor governance riddled by civil conflicts over the regions of natural resources. The foundational issues in the current outbreak lie in the political economies of the West African countries that have left the citizens of the affected nations poor with weak and struggling infrastructures. The numerous conflicts have made the West African nations susceptible to preventable diseases like EVD. Ecological studies also suggest that changes in climatic conditions around the West African country of Guinea enabled the Ebola virus to come in contact with humans. In order to achieve a long-term, sustainable control of EVD, the author admits that it is not enough to view the outbreak as just a result of a disease pathogen but to delve into the foundational causes of the disease outbreak which has made the West African nations susceptible to an infectious agent like the ebolavirus. These foundational causes are the outcomes of the political economies over natural resources in the West African nations. This paper suggests that governments of West African nations should develop a transborder framework for regions around natural resources and those governments should be more transparent with the people they govern. In addition, individuals and communities should take ownership in the prevention and control of EVD.

\section{Titilola T. Obilade MBBS, Ph.D.}

\section{Contact information:}

Titilola T. Obilade MBBS, MPH, FMCPH, MWACP, MILD, Ph.D.

Senior Education Specialist

Learning Sciences and Technology

144J Smyth Hall.

Virginia Polytechnic Institute and State University.

Blacksburg, Virginia, 24061- 0488.

झ obilade@vt.edu

Keywords

Ebola Virus Disease (EVD); filoviral hemorrhagic fevers; outbreak; West Africa; natural resource, political economy; civil conflicts; ownership; Guinea; governance 


\section{Introduction}

The Ebola virus disease (EVD) was first reported to have been identified in Africa in 1976. In 1976, an outbreak of a viral hemorrhagic disease occurred simultaneously in south Sudan and in Zaire (now Democratic Republic of Congo (DRC)) [1, 2]. The Ebola virus is responsible for one of the filoviral hemorrhagic fevers. The concept of viral hemorrhagic fevers was developed in the 1930's by Soviet investigators studying the hantavirus with renal syndrome [3].

In 1989, a different species of Ebola virus was isolated from cynomolgus monkeys (Macaca fascicularis) imported into USA. One hundred monkeys were imported from Manila, Philippines. Several of these monkeys began to die and necropsy findings isolated a new species of the Ebola virus. It was later named Reston Ebola virus after Reston, Virginia because the monkeys were housed in Hazelton Research Products in Reston, Virginia [4]. It was the first time that Ebola virus was isolated in USA [5].

In 1994, another species of Ebola virus was discovered when an ethnologist conducting necropsy on chimpanzees in the Tai Forest Park in Côte d'Ivoire got infected [6]. The Ebola virus species identified was later named Tai Forest Ebola Virus or Côte $d^{\prime}$ Ivoire Ebolavirus [7]. Since it was only one person that got infected, it cannot be considered an outbreak as such.

In 2002, necropsies conducted in insectivorous bats from caves in Spain isolated filoviruses similar to the Ebola virus but of a different genus that was later called Cuevavirus [8]. In 2007, an outbreak of viral hemorrhagic fever in the Bundibugyo District of Western Uganda was later identified to be caused by a new species of the Ebola virus. It was later named Bundibugyo Ebola virus [9].

Mononegavirales is the taxonomic order of Ebola viruses and filoviridae is the taxonomic family of Ebola viruses [10]. Filoviridae are filamentous. The name was derived from the morphological shapes of their virions that look like filaments, thread, cir- cular or U-shaped. Filo means thread or filament in Latin [11]. Two other genera belong to the filiviridae family; the Marburg virus (MARV) and the recently discovered Cuevavirus [8, 10]

Since 2014, Ebola virus has been responsible for the current EVD outbreak in West Africa especially in Liberia, Guinea and Liberia. Briefly, Nigeria had EVD when the index case from Monrovia, Liberia took a plane and flew from Liberia, changed planes in Lomé, Togo before landing in Lagos [12]. Similarly, Senegal had an index case that imported the disease from a Guinean traveler that travelled to Senegal in a seven person taxi [13].

Five Ebola virus species have been identified from the ebolavirus genus; The Sudan ebolavirus, the Zaire ebolavirus, the Bundiguyo ebolavirus, the Tai Forest ebolavirus and the Reston ebolavirus. The strain of Zaire ebolavirus that is responsible for the present outbreak is a variant of the Zaire Ebola virus from Democratic Republic of Congo (DRC) [14].The implication of this is that the ebolavirus that caused outbreaks in DRC is not the same variant. The current outbreak in West Africa does not show the same phylogenetic composition as the variants that caused the outbreak in DRC [14].

\section{Political Economy of West African Countries}

What made the ebolavirus that has never occurred in West Africa (apart from the lone infection with the Tai Forest ebolavirus) get into Guinea and from there spread to Liberia and Sierra Leone?

Why did it spread so rapidly? Even after the virus was identified why has it taken so long to curb the spread of the disease? Are there foundational problems in the political economies of these West African nations that make the control of EVD seem evasive? This paper would attempt to answer these questions.

West Africa has a population of 339 million people [15]. Endemic diseases like malaria kill thousands of people yearly. In 2012, there were over 300,000 
deaths from malaria [16]. Two thirds of the people that suffer from malaria are from West Africa [16]. The regions with the highest under five mortality rates are in West and Central Africa [17]. Twelve West African countries that make up $75 \%$ of West African nations are listed as members of least developed country [18]. Table 1 shows the list of West African countries that are members of Least Developed Country.

Table 1. List of West African Countries that are Members of Least Developed Country

\begin{tabular}{|l|l|}
$\begin{array}{l}\text { Member of Least } \\
\text { Developed Country }\end{array}$ & $\begin{array}{l}\text { Not a Member of Least } \\
\text { Developed Country }\end{array}$ \\
\hline Benin & $\begin{array}{l}\text { Cape Verde } \\
\text { Côte d'Ivoire }\end{array}$ \\
\hline Burkina Faso & Ghana \\
\hline $\begin{array}{l}\text { Guinea } \\
\text { Guinea-Bissau }\end{array}$ & Nigeria \\
\hline Liberia & \\
Mali & \\
\hline Mauritania & \\
Niger & \\
Senegal & \\
Sierra Leone & \\
Togo &
\end{tabular}

In the multi-dimensional poverty index (MPI), the poorest country is from West Africa [19]. Republic of Niger ranks as the poorest country using the MPI. In the United Nations Development (UNDP) Human Development Index; out of countries ranked between the $171^{\text {st }}$ and $187^{\text {th }}$ positions, nine of those countries are from West Africa. Republic of Niger ranks as the $187^{\text {th }}$ country out of 187 countries on the UNDP Human Development Index [20]. Table 2 shows the list of countries from the UNDP Human Development Index showing countries ranked between the $171^{\text {st }}$ and $187^{\text {th }}$ positions. The UNDP Human Development Index is a comparative measure of life expectancy, literacy, education and standard of living in all the countries of the world. A review of African Development Bank reports from 2007 to 2012 showed that an abundance of natural resources did not translate to an improvement of life of the citizens. Rather, an abundance of natural resources may signal the beginning of a downturn in the political economy of the country.

Table 2 List of Countries between the $171^{\text {st }}$ and $187^{\text {th }}$ position in the 2013 UNDP Human Development Index.

\begin{tabular}{|l|l|}
\hline Country & $\begin{array}{l}\text { UNDP Human } \\
\text { Development Index }\end{array}$ \\
\hline Côte d'Ivoire* & 171 \\
\hline Gambia* & 172 \\
\hline Ethiopia & 173 \\
\hline Malawi & 174 \\
\hline Liberia* & 175 \\
\hline Mali* & 176 \\
\hline Guinea-Bissau* & 177 \\
\hline Mozambique & 178 \\
\hline Guinea* & 179 \\
\hline Burundi & 180 \\
\hline Burkina Faso* & 181 \\
\hline Eritrea & 182 \\
\hline Sierra Leone* & 183 \\
\hline Chad & 184 \\
\hline Central African Republic & 185 \\
\hline DRC & 186 \\
\hline Niger* & 187 \\
\hline represents countries in West Africa \\
\hline Source: Adapted from UNDP Human Development \\
\hline Reports. Table 1: Human Development Index \\
\hline
\end{tabular}

\section{Natural Resources and Conflict}

However, despite the UNDP Human Development Index and the Multidimensional Poverty Index, West Africa is also home to natural resources like bauxite, iron ore, crude petroleum, diamonds and aluminum. Further, West African countries are exporters 
of products like cocoa beans and cotton [21] Table 3 shows the list of African nations with their main exports. Natural resources like diamond and crude petroleum are sources of main exports in countries like Sierra Leone and Nigeria.

Table 3. List of West African Nations and their Main Exports including their Natural Resources

\begin{tabular}{|c|c|}
\hline Country & Main Exports \\
\hline Benin & $\begin{array}{l}\text { Cotton, Edible nuts, Non-ferrous } \\
\text { Metal Waste }\end{array}$ \\
\hline Burkina Faso & Cotton \\
\hline Cape Verde & Fish \\
\hline Côte d'Ivoire & $\begin{array}{l}\text { Cocoa Beans, Crude Petroleum, } \\
\text { Cocoa Paste }\end{array}$ \\
\hline Gabon & $\begin{array}{l}\text { Crude Petroleum, Wood, Manganese } \\
\text { Ores }\end{array}$ \\
\hline Gambia & Edible nuts, \\
\hline Ghana & Cocoa beans, Manganese Ores, \\
\hline Guinea & $\begin{array}{l}\text { Aluminum Ore, Aluminum Oxide, } \\
\text { Copper Ores }\end{array}$ \\
\hline Guinea-Bissau & Edible Nuts \\
\hline Liberia & Ships, boats, Natural Rubber Latex \\
\hline Mali & Cotton \\
\hline Mauritania & Iron Ore, Molluscs, Fish \\
\hline Niger & Radio Active Chemicals \\
\hline Nigeria & Crude Petroleum \\
\hline Senegal & Inorganic Acid \\
\hline Sierra Leone & $\begin{array}{l}\text { Diamonds, Cocoa Beans, Cultivating } \\
\text { Machinery }\end{array}$ \\
\hline Togo & $\begin{array}{l}\text { Cocoa Beans, Natural Calcium } \\
\text { Phosphates, Cotton }\end{array}$ \\
\hline \multicolumn{2}{|c|}{$\begin{array}{l}\text { Source: Adapted from: African Development Report } \\
2007 \text { [21]. (Listed as [21] on the reference list. }\end{array}$} \\
\hline
\end{tabular}

\section{Natural Resources and Conflict}

Despite the natural resources and other valuable exports in the West African nations, about threequarters of them are among the lowest ranked in the UNDP Human Development Index [20, 21]. Researchers have also noted that armed conflicts usually occur around the regions of natural resources
$[22,23]$. The Mano River Region straddles Guinea, Liberia and Sierra Leone. Five civil conflicts occurred in the region between 1989 and 2004 [22]. These conflicts were the first and second Liberian civil war, the Sierra Leone civil war, the Guinean conflict and the first Ivoirian civil war [22]. The presence of diamonds and gold in the Mano River Region has positively correlated to the incidents of civil conflicts around the region [22].

\section{Ecology of the Most Affected Nations in the EVD Outbreak}

It has been suggested that climatic changes in temperature was another contributory factor in the index case coming from Guinea and for the spread of EVD in West Africa $[24,25]$. The index case in the current EVD outbreak was from Guinea, West Africa. Prior to the current outbreak, EVD had never been reported in any West African country not counting the single incident of an ethnologist that got infected in Tai Forest Park, Côte d'Ivoire [6].

Recent research has also shown that the mean temperature in Guinea is similar to the mean temperatures in countries like DRC and Gabon [24]. Gabon and DRC are both in East Africa. Gabon and DRC have had several outbreaks of EVD [24]. Sudan and Uganda have also had numerous outbreaks of EVD and research showed that the mean absolute humidity in Guinea was similar to that of Sudan and Uganda [24]. Further, there have also been prolonged dry seasons in Guinea which increases the risk of humans making contact with the animal reservoir. Deforestation from logging and clearing of land for agriculture also increase the risk of humans coming in contact with the suspected animal reservoir of EVD [25]. Mining for natural resources also increase the risk of human contact with potential animal reservoirs.

\section{Resultant Political Economy}

The civil conflicts around the areas of natural resources have not led to stable governments in 
these countries. Areas that do not have civil conflicts but are dependent on their natural resources for export have not invested in strengthening of their infrastructures. Similarly, the people in these countries have been impoverished despite an abundance of natural resources. The citizens of these nations have been left poor with weak and struggling infrastructures that cannot combat the EVD disease.

The term resource curse was first used by a British Economist, Richard Auty in 1993 [26, 27]. It is a paradox of plenty that describes how nations that have abundant resources tend to become impoverished while countries that have scarce resources tend to become rich [28]. It is not all African countries with abundant resources that tend to become impoverished. Botswana is the only country in Africa that has avoided conflicts despite its resources in diamonds [29]. Liberia and Sierra Leone both had civil wars in the1990's that was related to diamonds and gemstones [30]. Nigeria had the Biafra war between 1967 and 1970 that was related to oil [30]. However, it is not all conflicts that are related to natural resources. There were more than 80 violent changes in governments in African countries between 1960 and the 1990's [31].

A 2007 report by the African Development Bank identified several factors associated with the paradox of plenty in countries with natural resources [21]. There were exacerbations of inequalities in the people, enhanced corruption and rent seeking, governments making poor investment decisions, poor governance, less prudent policies, lack of transparency and poor macroeconomic management [21]. Rent seeking behavior impoverishes the economy. Further, the report also showed that resource-scarce countries outperformed resource-rich countries in growth although overall, the resource-rich countries still had more wealth than the resource-scarce countries [21].

\section{Foundational Issues in Combating EVD in West African Countries}

In the English folk tale of the big, bad wolf; the only house the wolf was not able to blow down was the house built with bricks. It was able to blow down the house made with straw and the one made with furze [32]. The foundation of the house built with bricks was strong enough to withstand the challenging, puffing of the bad wolf.

The point of including the folktale in my review is to illustrate the foundational issues in West African countries especially in the countries most affected by EVD. In the present context of the current EVD outbreak, the existing foundational issues in the political economies of the three most affected countries implies that they are not able to withstand the challenges brought on by the current EVD outbreak. Prior to the existing situation, the foundational infrastructure that would have been used to combat the diseases was scarce and if they existed, they were inadequate.

The political economies of West African nations also provided a poor foundation for the health system and a ripe environment for the Ebola virus to prey on. Therefore, short-term solutions may not necessarily resolve the foundational issues in the political economies of the West African countries. West African nations should be looking at long term solutions. These foundational issues have led to mistrust of the government, fatal antagonism of health care workers, hospital vandalism and removal of EVD patients by their relatives, EVD stigmatization and lack of basic infrastructure [33, 34].

\section{The Way Forward}

The underlying problem in the present EVD outbreak goes beyond treating EVD patients. The Governments of West African nations need to be transparent and should collaborate with one another. The people of the affected countries need to take ownership in the prevention and control of EVD 
[35]. West African countries with natural resources should collaborate with countries like Botswana that also have natural resources like diamond but have not had conflicts.

Individual Level: Instead of waiting to get infected and then being treated, individuals and communities should pro-actively prevent themselves from getting infected and they should self- identify and self-isolate if they get infected [35].

Community Level: At the community level, survivors of EVD are a good resource for health education and for debunking the stigma attached to EVD [36]. Survivors of EVD can become village health workers in their communities. Health education should respectfully debunk myths surrounding EVD. Members of the community that have a clout in the community should be trained to become health educators in the community and welcome EVD survivors who need to be re integrated back into the community. They can also support those who selfidentify as having a rise in temperature or who may have come in contact with an EVD patient. They can support them through provision of food and other basic necessities.

Village health workers (VHWs): Health care workers have lost many of their members to EVD and to fatal antagonism from community members $[37,38]$. Village health workers can reach the areas that may not be accessible to health care workers. Village health workers have been successfully employed by many countries to reach rural and remote areas that professional health workers are not able to reach [39]. Uganda has successfully employed VHWs in recent EVD outbreaks [40]. Village health workers should be members of the community that have been selected by the community. They can counsel EVD survivors and members of the community that would need counsel before reintegrating EVD survivors back into their community.

Government Level: West African nations should also develop a transboundary framework among areas of natural resources to prevent conflict. The
Governments of affected nations should make resources available for health education through use of posters, mobile phones, newspapers, and all forms of digital media. The governments should provide village health workers with mobile phones and bicycles or motor cycles for tasks like contact tracing. Posters written in the local language of the people promote a sense of ownership. Figure 1 is a poster written in the local language. The governments should provide the basic infrastructure for potable water, waste and refuse disposal. The schools are a good resource for health education. They should not be closed except they have distance learning options and if schools should close; they should be for short periods. Teachers can be incorporated as health educators to teach the school children about the control of the EVD.

Cross border surveillance: Cross border surveillance should be strengthened so that infected travelers attempting to travel out are prevented. Boundaries over the land, sea and airports should be secured against infected persons that might want to cross the borders. The most affected nations should collaborate with countries like Nigeria and Senegal that have successfully stopped the transmission of the EVD. They should also collaborate with other African nations like Uganda and DRC that have had numerous EVD outbreaks. The Democratic Republic of Congo had its seventh EVD outbreak in July 2014 and by the 22nd of November, 2014 it was declared free from EVD transmission by the World Health Organisation [41, 42]. The current outbreak in West Africa and the one in DRC were not related.

International Organizations: International Organizations should continue in their efforts but must maintain sustainable plans that can be carried out even after the outbreak becomes controllable. 
Figure 1: A poster on EVD in the local language. Used with permission from UNICEF.

\section{Omanya ebikwete aha EBOLA}

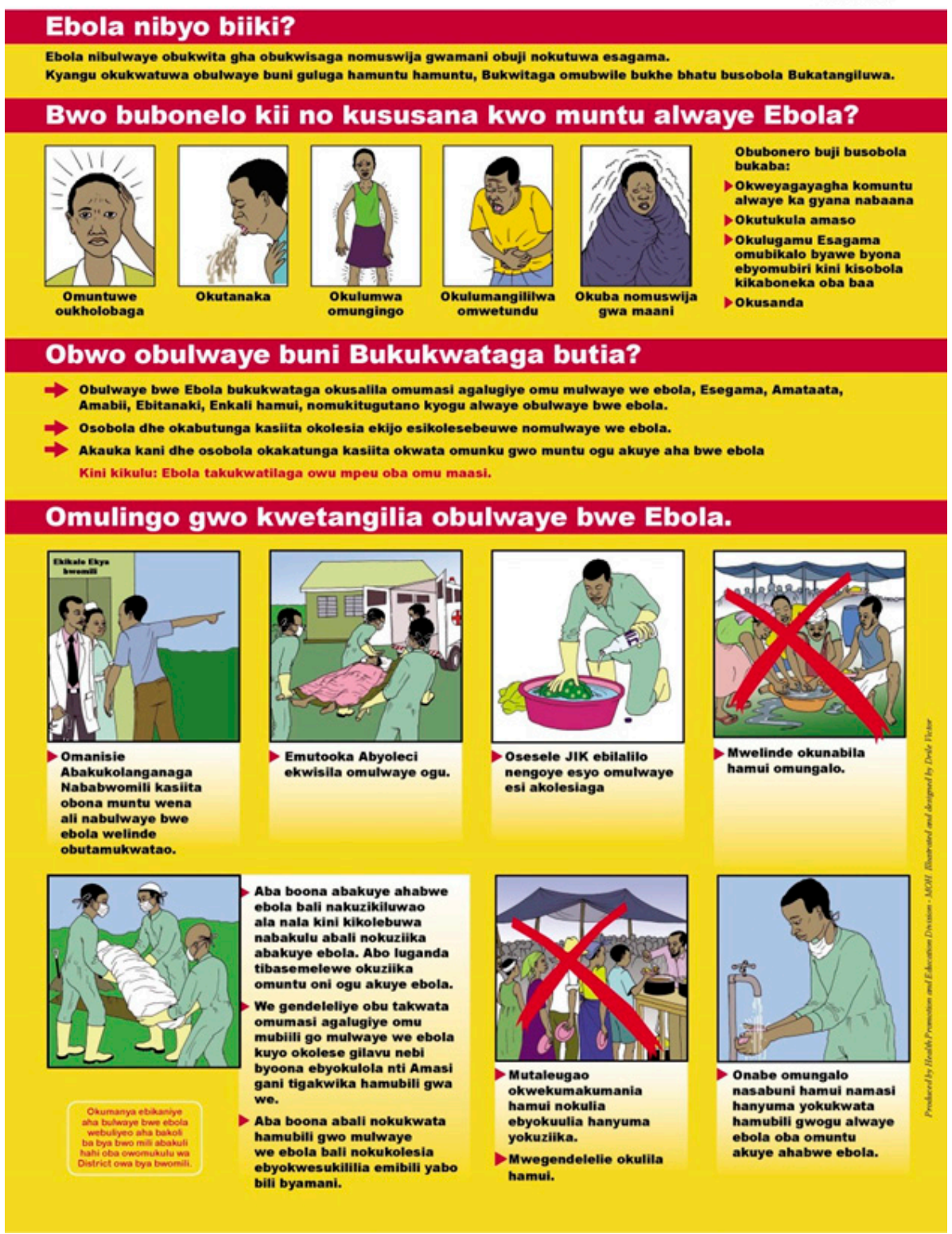




\section{Conclusion}

It is not enough to look at the current outbreak as a disease occurrence alone. Rather, we should delve into the foundational causes of what has made the West African nations a prolonged source of EVD. The various causes identified included the climatic changes in Guinea from where the index case was reported, the paradox of plenty in the West African nations that have abundant natural resources that have led to numerous conflicts, the governments making less prudent policies thereby increasing the inequalities between the rich and the poor. Instead of treating EVD patients which is a short term solution to the ongoing crisis, this paper suggested ways that can give sustainable long term solutions that would prevent the resurgence and spread of rapid killing infectious diseases. If it was not the ebolavirus, another class 4 pathogen could have caused the crisis.

Health education, community and individual ownership in the prevention and control of EVD were identified as a form of control. Cross border surveillance and collaboration with International Organizations were also identified as a sustainable form of control of EVD. Governments of abundant resource countries should collaborate with a West African country like Botswana that has diamonds but has not been embroiled in civil conflicts over their natural resources. Survivors of EVD can serve as a resource for health education and can also be an avenue to reduce stigmatization of the disease.

\section{Conflict of Interest}

None

\section{Acknowledgments}

There was no funding in writing this article. The author acknowledges UNICEF for the permission to use the poster in Figure $\mathbf{1 .}$

I would also like to acknowledge Virginia Polytechnic Institute and State University's Open Access Subvention Fund (OASF). 


\section{References}

1. Report of a WHO/International Study Team. Ebola Haemorrhagic Fever in Sudan, 1976. Bull. World Health Organ. 1978, 56, 247270.

2. Report of an International Commission. Ebola Haemorrhagic Fever in Zaire, 1976. Bull. World Health Organ. 1978, 56, 271 293.

3. Gajdusek, D. C. (1962). Virus hemorrhagic fevers: special reference to hemorrhagic fever with renal syndrome (epidemic hemorrhagic fever). The Journal of pediatrics, 60 (6), 841-857.

4. Jahrling, P., Geisbert, T., Johnson, E., Peters, C., Dalgard, D., \& Hall, W. (1990). Preliminary report: isolation of Ebola virus from monkeys imported to USA. The lancet, 335 (8688), 502-505.

5. Dalgard, D., Hardy, R., Pearson, S., Pucak, G., Quander, R., Zack, P. Jahrling, P. (1992). Combined simian hemorrhagic fever and Ebola virus infection in cynomolgus monkeys. Laboratory animal science, 42 (2), 152-157.

6. Le Guenno B, Formenty P, Wyers M, et al. Isolation and partial characterisation of a new strain of Ebola virus. Lancet 1995; 345: 1271-1274

7. Martines RB, Ng DL, Greer PW, Rollin PE, Zaki SR. Tissue and cellular tropism, pathology and pathogenesis of Ebola and Marburg viruses. J Pathol. 2015; 235(2):153-74.

8. Negredo, A.; Palacios, G.; Vázquez-Morón, S.; González, F.; Dopazo, H.; Molero, F.; Juste, J.; Quetglas, J.; Savji, N.; de la Cruz Martínez, M.; et al. Discovery of an ebolavirus-like filovirus in europe. PLoS Pathog. 2011, 7, e1002304

9. Towner, J. S., Sealy, T. K., Khristova, M. L., Albariño, C. G., Conlan, S., Reeder, S. A., Tappero, J. W. (2008). Newly discovered ebola virus associated with hemorrhagic fever outbreak in Uganda. PLoS pathogens, 4(11), e1000212.

10. Paessler $S$, Walker DH. Pathogenesis of the viral hemorrhagic fevers. Annual review of pathology. 2013; 8: 411- 440.

11. Kiley M, Bowen E, Eddy G, Isaäcson M, Johnson K, McCormick J, et al. Filoviridae: a taxonomic home for Marburg and Ebola viruses? Intervirology. 1982; 18(1-2): 24-32.

12. Shuaib, F.; Gunnala, R.; Musa, E.O.; Mahoney, F.J.; Oguntimehin, O.; Nguku, P.M.; Nyanti, S.B.; Knight, N.; Gwarzo, N.S.; Idigbe, O.; et al. Ebola Virus Disease Outbreak-Nigeria, July-September 2014. MMWR Morb. Mortal. Wkly. Rep. 2014, 63, 867-872.

13. Mirkovic, K.; Thwing, J.; Diack, P.A. Importation and containment of Ebola virus disease-Senegal, August-September 2014. MMWR Morb. Mortal. Wkly. Rep. 2014, 63, 873-874.

14. Baize S, Pannetier D, Oestereich L, Rieger T, Koivogui L, Magassouba NF, et al. Emergence of Zaire Ebola Virus Disease in Guinea. N Engl J Med. 2014; 371(15): 1418-1425.

15. PRB. Population Reference Bureau 2014 World Population Data Sheet. [cited 2014 December, 28]. Available from: http://www. prb.org/pdf14/2014-world-population-data-sheet_eng.pdf
16. WHO Malaria World Report; 2013. Nigeria [cited 2014 November 28] Available from: http://www.who.int/malaria/publications/ world_malaria_report_2013/wmr2013_country_profiles. pdf?ua=1

17. UNICEF. The State of the World's Children's Report 2015 Statistical Tables. [cited 2015 February, 5]. Available from: http://www.data.unicef.org/corecode/uploads/document6/ uploaded_pdfs/corecode/SOWC_2015_Summary_and_Tablesfinal_214.pdf

18. United Nations. UN List of Least Developed Countries. [cited 2015 February, 5]. Available from: http://www.un.org/en/ development/desa/policy/cdp/ldc/ldc_list.pdf

19. OPHI. Oxford Poverty and Human Development Initiative; How disaggregated metrics help to reduce multidimentional poverty. [cited 2015 February, 5]. Available from: http://www.ophi. org.uk/wp-content/uploads/Global-MPI-highlights-briefingJan-2015.pdf

20. UNDP Human Development Reports. Table 1: Human Development Index and Its Components. [cited 2015 February, 5]. Available from: http://hdr.undp.org/en/content/table-1human-development-index-and-its-components

21. African Development Bank African Development Report 2007. Africa's Natural Resources: The Paradox of Plenty 13:54 pp. 96140. [cited 2015 February, 5]. Available from: http://www.afdb. org/fileadmin/uploads/afdb/Documents/Publications/(E)\%20 AfricanBank\%202007\%20Ch4.pdf

22. Balestri, S.; Maggioni, M.A. Blood diamonds, dirty gold and spatial spill-overs measuring conflict dynamics in West Africa. Peace Econ. Peace Sci. Public Policy 2014, 20, 551-564.

23. BBC. Guinea Turmoil Threatens Mine Deal. [cited 2014 December, 28]. Available from: http://news.bbc.co.uk/2/hi/africa/7544046. $\mathrm{stm}$

24. Ng, S.; Basta, N.E.; Cowling, B.J. Association between temperature, humidity and ebolavirus disease outbreaks in Africa, 1976 to 2014. Euro surveillance: Bulletin Européen sur les maladies transmissibles. Eur. Commun. Dis. Bull. 2014, 19, pii=20892.

25. Bausch, D.G.; Schwarz, L. Outbreak of Ebola virus disease in Guinea: Where ecology meets economy. PLoS Negl. Trop. Dis. 2014, 8(7) e3056. doi:10.1371/journal.pntd.0003056. Available from: http://journals. plos.org/plosntds/article?id=10.1371/ journal.pntd.0003056

26. Auty RM Sustaining Development in Mineral Economies: The Resource Curse Thesis. 1993; London: Routledge.

27. Time. Brief History;The Resource Curse. [cited 2015 January, 28] Available from: http://content.time.com/time/magazine/ article/0,9171,1997460,00.html

28. Sachs JD, Warner AM. The big push, natural resource booms and growth. Journal of development economics. 1999; 59(1): 43-76. 
29. Olsson O. Conflict diamonds. Journal of Development Economics. 2007; 82(2): 267-286.

30. Ross ML. What do we know about natural resources and civil war? Journal of Peace Research. 2004; 41(3): 337-356.

31. Adedeji A. Comprehending African Conflicts: Sub-Sahara Africa, a violent continent. In A. Adedeji (Ed.), Comprehending and Mastering African Conflicts: The Search for Sustainable Peace and Good Governance. London: Zed: 1999: 3-21.

32. Jacobs A. English Fairy Tales; The Story of the Three Little Pigs.pp.68- 72, 1890. David Nutt: London. [cited 2015 February, 6]. Available from: https://archive.org/details/ englishfairytal00jacogoog

33. The Guardian. Risk Unheeded as Guinea's Villagers Keep on Eating Fruit Bats; Health Workers Struggle to Separate Myth from Reality of Ebola as Residents Say Abandoning Tradition is Out of the Question. [cited 2015 February, 6]. Available from: http://www.theguardian.com/global-development/2014/ aug/04/ebola-risk-guinea-fruit-bats

34. BBC. Ebola Outbreak: Guinea health team killed. 18 Sept 2014. [cited 2015 February, 6]. Available from: http://www.bbc.com/ news/world-africa-29256443

35. Obilade TT. The Political Economy of the Ebola Virus Disease (EVD); Taking Individual and Community Ownership in the Prevention and Control of EVD. Healthcare 2015, 3, 36-49; doi:10.3390/healthcare3010036. [cited 2015 February, 6]. Available from: http://www.mdpi.com/2227-9032/3/1/36

36. Obilade TT. Ebolavirus disease stigmatization: The role of societal attributes. Int Arch Med. 2015; 8(14) 1-19. doi: 3823/1613. [cited 2015 March, 3]. Available from: http://imed.pub/ojs/index.php/ iam/article/view/1007/674

37. Green A. Remembering health workers who died from Ebola in 2014. The Lancet. 384(9961):2201-2206.

38. WHO. Report by the Director-General to the Special Session of the Executive Board on Ebola. [cited February 26, 2015]. Available from: http://www.who.int/dg/speeches/2015/executive-boardebola/en/
39. WHO. Health by the people. 1975. [cited 2015 February, 26]. Available from: http://apps.who.int/iris/ bitstream/10665/40514/1/9241560428_eng.pdf

40. Mbonye AK, Wamala JF, Nanyunja M, Opio A, Aceng JR, Makumbi I. Ebola viral hemorrhagic disease outbreak in west Africa-lessons from Uganda. African health sciences. 2014; 14(3): 495-501.

41. Maganga, G.D.; Kapetshi, J.; Berthet, N.; llunga, B.K.; Kingebeni, P.M.; Mondonge, V.; Mondonge, V.; Muyembe, J.T.; Bertherat, E.; Briand, S.; et al. Ebola virus disease in the Democratic Republic of Congo. N. Engl. J. Med. 2014, 371, 2083-2091.

42. WHO. WHO Declares End of Ebola Outbreak in the Democratic Republic of Congo. [cited 2015 February, 6]. Available from: http://www.who.int/mediacentre/news/statements/2014/drcends-ebola/en/

\section{Comment on this article:}

\section{$4[8$ in $8+\mathbf{S} P$}

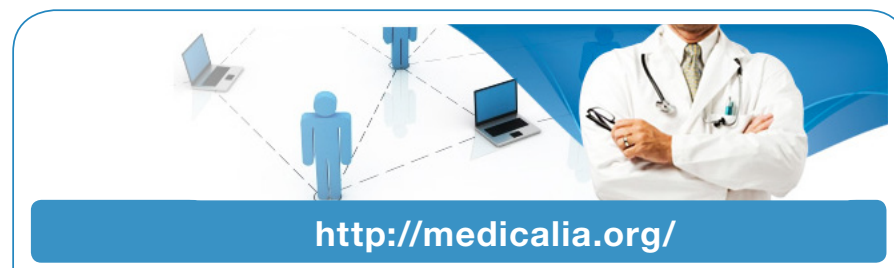

Where Doctors exchange clinical experiences, review their cases and share clinical knowledge. You can also access lots of medical publications for free. Join Now!

\section{Publish with iMedPub}

http://www.imed.pub

International Archives of Medicine is an open access journal publishing articles encompassing all aspects of medical science and clinical practice. IAM is considered a megajournal with independent sections on all areas of medicine. IAM is a really international journal with authors and board members from all around the world. The journal is widely indexed and classified Q1 in category Medicine. 